\title{
“I SUFFER FROM BORDER SYNDROME": THE PALIMPSEST OF BORDERS IN TRANSCULTURAL TEXTS OF MIGRATION
}

\begin{abstract}
In a globalised world in which 68.5 million people are migrants, the representation of borders and border crossers in the media is a controversial issue. This article explores how transcultural literature moves beyond one-dimensional depictions of borders and migrants and instead creates differentiated perspectives. Gazmend Kapllani's $A$ Short Border Handbook (2009 in Greek, translated into English in 2010) and Kapka Kassabova's Border: A Journey to the Edge of Europe (2017, written in English) both revolve around a "border syndrome", an illness incorporating a fear of the border and a simultaneous urge to transgress it, as well as a fascination with liminality. This article argues that these literary texts narrate borders as palimpsests of different temporalities and geographies, of external and internal as well as political and metaphysical borders, which accounts for the complexity and ultimate incurability of the "border syndrome".
\end{abstract}

Key words: transcultural literature, migration, borders, palimpsest, life-writing

\section{Borders and the palimpsest: Interwoven stories - interwoven layers}

In a globalised world in which 68.5 million people are migrants, the representations of borders and border crossers are contested and conflicting issues in various media. The trajectory of this article is to show how transcultural literature can move beyond one-dimensional depictions of borders and instead create differentiated perspectives by storytelling. Gazmend Kapllani's generically hybrid A Short Border Handbook (2010) deals with the author's story of migration from Albania to Greece, while in Kapka Kassabova's Border: A Journey to the Edge of Europe (2017) its author, who comes from Bulgaria and now lives in Scotland, visits the border zone between Bulgaria, Turkey, and Greece. Shaped by successive historical phases of migration from antiquity to the Cold War until today's "Balkan Route", it is explored in the form of generically hybrid stories.

\footnotetext{
"Department of English Literary and Cultural Studies, Neuphilologisches Institut, Julius-MaximiliansUniversity Würzburg, Am Hubland, 97074 Würzburg, Germany; e-mail: miriam.wallraven@uniwuerzburg.de
} 
Both texts revolve around a "border syndrome", an illness incorporating a fear of the border and a simultaneous urge to transgress it, as well as a fascination with liminality and in-between zones. In my analysis, I argue that the texts narrate borders as palimpsests where seemingly unrelated stories become interwoven and communicate with each other. Therefore, it will be shown how A Short Border Handbook and Border envision borders as palimpsests of different temporalities and geographies, of visible and invisible, of external and internal as well as political and metaphysical borders, which accounts for the complexity and ultimate incurability of the "border syndrome".

In these literary texts, a border does not constitute a one-dimensional point of crossing into another country as it is often depicted in the media, but it has to be understood, visualised, and approached as a palimpsest. Originally, the palimpsest is a parchment or another writing material which has been written upon twice or even more times, while each time the original writing has been erased or rubbed out in order to make space for yet another layer of writing. Thus, it signifies a manuscript in which a later writing is written over an effaced earlier text. Since the writing has often been erased imperfectly, traces of the previous, underlying story are still present; as Dillon argues, "The palimpsest is an involuted phenomenon where otherwise unrelated texts are involved and entangled, intricately interwoven, interrupting and inhabiting each other" (Dillon 2005: 245). The concept of the palimpsest as the image of the medieval manuscript and its layers that shine through and are written on top of each other has been utilised as a metaphor for various cultural phenomena to illustrate how life and indeed the whole world consists of stories written on other stories.

The palimpsest can thus be characterised by temporal layers of stories, a historical simultaneousness which has also been applied to the understanding of borders. Kinossian and Wrakberg employ the concept in order to interpret symbolic landscapes in Norwegian-Russian and Lithuanian-Russian borderlands and refer to Sarah Dillon's seminal work. They argue that "when applied to symbolic landscapes, the palimpsest can shed light on interactions between the past and the present. Historical layers are often perforated, with underlying layers shining through later sediments" (Kinossian and Wrakberg 2017: 91). Furthermore, they suggest trying to recognise the palimpsest as a model and a tool "to facilitate seeing the borders not only between states, economic systems or social identities, but also between the layers in the heritage and memoryscape of a town or region" (Kinossian and Wrakberg 2017: 107). In order to investigate the intricate interplay of different layers of borders, I would like to go further by analysing the borders in the two texts, A Short Border Handbook and Border, as palimpsestic in a more complex way transcending a mere concern with historical layers.

Both authors, Kapllani and Kassabova, stress the importance of stories and storytelling for an understanding of borders, border crossing, and migration. Kapllani 
for instance highlights the importance of stories by stating "You cannot understand a migrant if you haven't heard his story first" (Kapllani 2010: 5), while Kassabova explains her motivation for the writing of her book as "Looking for stories about the border" (Kassabova 2017: 45) - eventually, I want to argue, the only way of getting to know a border, the ensuing "border trouble" (Kassabova 2017: 252), and the "border syndrome" that both texts thematise.

On a general level, Rosello and Wolfe stress the significance of a narrative focused on border crossing for a nation: "Consequently, the border-crossing narrative (as manifest in travel writing, exploration narratives, captivity narratives, autobiographical writing, migration literature, etc.) can thus be apprehended as performative renegotiations of nations and their narration, as well as the border itself" (Rosello and Wolfe 2017: 2). Such narratives of border crossings, however, cannot only be read as "performative renegotiations" of national narrations but beyond that also of histories, cultures, and perspectives.

\section{2. "Border syndrome is an illness that's difficult to describe": Gazmend Kapllani's A Short Border Handbook}

A Short Border Handbook is a genre hybrid interweaving Kapllani's experiences with living in totalitarian Albania - a life characterised by oppression, surveillance, and desperate attempts to cross the border - as well as his story of escape and being a refugee in Greece with general theoretical reflections on borders and information on migration. The different parts in the narrative enter into a dialogue with each other and are marked by different typescripts. Since borders have complex effects on human beings, and crossing the border of totalitarian Albania turns out to be a difficult if not impossible venture, the title A Short Border Handbook is of course deliberately ironic; however, as will be seen, it can indeed be read as a handbook contributing to a more differentiated understanding of multiple intersecting layers of borders.

From the beginning of the book, the mysterious "border syndrome", an illness that draws attention to the border's power to affect the human body and psyche in various ways, and the geographical borderline are seen as intimately intertwined. Hence, the narrator states: "Border syndrome is an illness that's difficult to describe with precision" (Kapllani 2010: 2) specific to people who are forbidden to cross a border: "Those who have never experienced the urge to cross a border, or who have never experienced rejection at a border, will have a hard time understanding us" (Kapllani 2010: 2). He explains that "whether or not you end up with border syndrome is largely a matter of luck: it depends on where you're born. I was born in Albania" (Kapllani 2010: 2). In this regard, the "mysterious" illness might be mysterious on a psychological and bodily level, but it can be traced back to the political border of the 
totalitarian regime. The "border syndrome" hence makes it clear from the beginning that a border is never simply a geographical or political demarcation but is made up of various layers affecting the human being as a whole.

The first layer of the border is the imaginary one. Since the material geographical border is not accessible for Albania's citizens, the imaginary border gains what Kapllani calls "metaphysical dimensions": "Artur's death shocked me deeply. It also fired my imagination, and gradually the borders took on metaphysical dimensions for me. They haunted my sleep, and nothing pleased me more during my waking hours than listening to stories which were in some way connected to borders: arrests, killings, attempted escapes, most of which had failed" (Kapllani 2010: 26). Here, the reason as well as the cure for his being haunted seems to be listening to stories of the border. Storytelling thus becomes the medium to access the border as well as the fear of the border, the otherwise inaccessible "metaphysical dimension". The border thus becomes an internal phenomenon - the layers of external and imagined border interweave in a palimpsestic way.

In the narrative, the imaginary border extends to the people who succeed in crossing it, those who emigrate. Since exit visas exist only for a select few, those people become an imaginary breed apart, indeed "extra-terrestrials" (Kapllani 2010:3) for the narrator. While it is evident that the border separates whole families, those who manage to cross the border are attributed an almost mythological status in the minds of the people who are forced to stay:

To me the few who managed to get out were the strongest, most special people in the entire world. Some were even from our town. Everyone knew about them, not just because they'd escaped, but because of the repercussions and the terror that followed. Their families were sent into exile, their relatives lost their jobs, forever stigmatized for having an 'enemy of the people' in their family. (Kapllani 2010: 26-27)

The border crossers become "the strongest, most special people" in the imagination whereas the families of the émigrés are directly affected by the consequences. In this instance, the border is present both as imaginary and as political. This interrelatedness of layers emphasises its intricate complexity and thus accounts for the mysterious "border syndrome" and the lack of a cure for it.

The internalisation of the border brought about by Albanian totalitarianism is presented with heavy irony throughout the whole book: "In our minds, the world was divided into two - Paradise (us) and Hell (everyone else), and whoever tried to cross the borders of paradise and escape was automatically branded Hell's accomplice. For 
that reason, passports were abolished as we had no use for them, and attempts to escape from Albania were considered high treason" (Kapllani 2010: 21). The internalisation is premised on the division "in our minds", but time and again this division is questioned, since, as Kapllani writes, "We were condemned to speculate endlessly about what lay on the other side of the borders" (Kapllani 2010: 3). This speculation counters the internalised border which the regime attempts to create: The representation of the border by propaganda is thus counteracted by stories and imagination. Hence, despite the fact that "The regime did everything in its power to block all images from the other side of the border by means of controls, arrests, and punishments" (Kapllani 2010: 6), those prohibited images are created by the imagination as images of border crossing as well as images of a world beyond the border.

In this way, speculation, imagination, and storytelling already signify instances of border crossing: "We each had our own ideas on the subject, usually the product of rumours, or pictures we'd seen on television, transformed into mythical stories, which we'd use to feed our fantasies as much as we could" (Kapllani 2010: 30). Imagination and storytelling thus effectually lead to the transgression of the internalised borders and eventually create the desire to cross the geographical border. In her book Terra Infirma, Rogoff justly argues:

links are set up between the border as a psychically internalized concept of boundaries crossed and repression breached and the external traces of a containment which holds one in, which does not allow for that very breach. It is this tension between internal fantasmatic border crossing and external collective armed containment which gives the 'border' its current cultural frisson. (Rogoff 2000: 113)

This tension is at the centre of the first part of Kapllani's book whereas it is underscored that the border conceptualised as a palimpsest created by storytelling is already continually crossed and transgressed. The forbidden aerials for picking up Italian channels contest the border (Kapllani 2010: 8), and looking at the light across the border and imagining life there likewise constitute acts of crossing the internalised border: "I remember our school trip to Sarandë, where at night you can see the lights from the world-beyond-the-borders" (Kapllani 2010: 29).

In addition, material things from across the border acquire great value because in those objects the lands from across the border materialise and bridge the otherwise unconnected worlds: "In place of this terrifying enemy, the sea would wash up several humble objects from the world-beyond-the-borders: disintegrating sacks, empty CocaCola bottles, empty cartons of washing powder bearing various slogans and brand 
names. People would often take these things home and decorate their houses with them" (Kapllani 2010: 36). These things, the waste of consumer culture, take on "fetish-status" (Kapllani 2010: 36), since they manifest "the determination of people to cling on to the slightest contact with the world-beyond-the-borders" (Kapllani 2010: 36). By that, a relationship with the outside world is established, and eventually the border loses its absolute existence. As Decker and Winchock argue in their work on borderlands and liminality, "A border, however, is more than just a physical limit: it is also the limit of ideas" (Decker and Winchock 2017: 1). Although the readers would certainly expect this to hold true particularly for borders in totalitarian systems where their internalisation by the subjects is of prime political importance, this equation fails in The Border Handbook precisely because the border is made up of numerous layers forming a palimpsest. According to Decker and Winchock, "To transgress borders, then, we must do more than simply cross a line: we must be willing to break apart our old worldviews and reassemble them into something that allows us to navigate, survive, and bridge the liminal territory between binaries" (Decker and Winchock 2017: 5). The transgression of the border in A Short Border Handbook indeed tests the limits of the concept itself.

In "A Preface to Transgression", Michel Foucault argues that:

Transgression is an action which involves the limit, that narrow zone of a line where it displays the flash of its passage, but perhaps also its entire trajectory, even its origin; it is likely that transgression has its entire space in the line it crosses. [...] The limit and transgression depend on each other for whatever density of being they possess: a limit could not exist if it were absolutely uncrossable, and, reciprocally, transgression would be pointless if it merely crossed a limit composed of illusion and shadows. (Foucault 1998: 27)

Furthermore, he states that "Transgression carries the limit right to the limit of its being; transgression forces the limit to face the fact of its imminent disappearance" (Foucault 1998: 28). In this way, in Kapllani's text the border designed in the totalitarian regime to separate countries, worldviews, and people ceases to exist as a monolithic entity. If the palimpsest that constitutes a border comprises layers of visible and invisible as well as external and internal, political and metaphysical borders, then transgressing one layer paves the way for transgressing the others as well. Consequently, in the text, the narrator and other people finally dare to attempt crossing the political and geographical border and, since they are successful, they become migrants - the border crossers per se. 
However, since even after crossing the border, the border palimpsest remains central, stories are not only of prime importance for understanding the border in its many layers, but they remain a crucial method of survival for the migrant, which testifies to the power of literature as the medium for complex processes of telling such stories. Therefore, one of the main topics that the second part of The Border Handbook pivots on is the fact that after crossing the border between Albania and Greece, the palimpsest of borders that has characterised life in totalitarian Albania still remains relevant, indeed life-determining:

The migrant is a creature surrounded by borders. Conventional borders, the ones that divide one country from another, mean little to him, they are just large, visible borders. There are thousands of invisible borders, however, awaiting him every minute of every day, awaiting his every move almost, his every desire and ambition. The language: behold the first invisible border. (Kapllani 2010: 79)

Here, these borders are described as living entities, almost as predators. The palimpsest of invisible borders in the new country is hardly legible for the migrant since there are again many borders written over each other obscuring their full visibility. Such borders are obviously mechanisms of racist exclusion; for instance, the sign that excludes foreigners from renting a flat constitutes yet another - this time tangible border: "when you try to rent a flat and read the sign on the door saying 'No foreigners. No pets"” (Kapllani 2010: 83).

The border palimpsest that affects the migrant also includes the border stories by those who have just escaped: "The new ones told us stories, stories that made our hair stand on end" (Kapllani 2010: 100), and "Other people were telling stories about wolves attacking exhausted fugitives, tearing them to pieces" (Kapllani 2010: 100). Even after migrating, a conceptualisation of the border is only possible by stories and storytelling. Similarly, the layer of the imagined border remains relevant, since the real encounter with the world beyond the border where the migrant is met by hatred, racism, and exclusion leaves him disappointed precisely due to the imaginary border which served the creation of an ideal world: "You created in your mind a world of harmony and beauty, and with this construct in your head, you crossed the borders" (Kapllani 2010: 102). In this sentence, the connection between crossing an imaginary border and crossing a geographical border are once again highlighted. What emerges clearly in this respect is the fact that the palimpsest of borders continues to affect the migrant long after crossing over into the other country. Rosello and Wolfe emphasise the effects of borders in their work: 
We suggest that borders can have a life of their own, producing border effects after their original installation or statement; they can reinforce their symbolic difference that created them, or even cause changes in these symbolic differences; they can continue to have effects after the symbolic differences that caused them have disappeared or lessened. Border formation can include an element of unpredictability and uncanny effects coming from the border itself. (Rosello and Wolfe 2017: 2)

One of those uncanny effects in The Border Handbook is subsumed under the term "border syndrome" which is complicated by the palimpsestic layers constituting the border:

Tales of monstrous, visible borders such as the borders of totalitarianism and tales of the invisible, psychological borders experienced in a foreign country rarely reach a conclusion. It was never the intention to tell you the story of my life; what I wanted to tell you about was my illness, border syndrome, a condition that you won't find documented in any manual of recognized psychological disorders. (Kapllani 2010: 151)

This "border syndrome" - for which the author utilises various medical terms such as illness, syndrome, or disorder, which testifies to the difficulty he encounters to accurately describe it - can only be understood by storytelling; here, literature functions as the medium to describe, visualise, and discuss the different layers of borders that are all interwoven.

Despite the storytelling as necessary and partly therapeutic measure, this "border syndrome" cannot be cured, as the narrator states:

Nevertheless, border syndrome is just as pernicious as the hepatitis virus because you can never truly get rid of it. It just sits there, in a latent state, wedged between time and space, wedged between your body and the gaze of others, ready to strike at any moment and take possessions of your memories, your silence, the expression in your eyes, your spleen, your smile, your passion and your life. (Kapllani 2010: 152)

A Short Border Handbook also makes visible the fact that it depends on the place of birth whether someone suffers from this illness: "To work out how much you are at risk of contracting the border syndrome virus, all you need to do is remember which side of the border you were born on" (Kapllani 2010: 152). Borders unfold their full 
effects long after one of its layers, the border line that can be located geographically, has been crossed.

\section{3. "Maybe it was a border syndrome, I said": Kapka Kassabova's Border: A Journey to the Edge of Europe}

The second text that offers an intricate literary exploration of the multifaceted forms and effects of borders is Kapka Kassabova's Border: A Journey to the Edge of Europe (2017). In this text, the author, who has migrated from Bulgaria to New Zealand and now lives in Scotland, visits the border zone between Bulgaria, Turkey and Greece which was a central but extremely dangerous crossing point into the West during the Cold War. Shaped by successive historical phases of migration - until today's "Balkan Route" - this border zone is examined in the form of generically hybrid stories.

The first strand of the text, which can be described as life-writing narrating the author's own story of emigration to New Zealand, is interwoven with a second strand consisting of mythology that contains folk songs and tales (for example Rhodope mythology) while describing traditions from the Strandja region, which is revealed to be a mythical and supernatural place - and of course a border zone. Whereas one part of the book can be characterised as a narrative of border crossing and migration, the second part turns out to be a travelogue in which Kassabova undertakes the journey back into Bulgaria's border zone as a tourist. In addition, the text also comprises theoretical reflections on the history of the border zone as well as on borders in general.

The book consists of an interweaving of different stories, since the author is "Looking for stories about the border" (Kassabova 2017: 45) and states that "This book tells the human story of the last border of Europe" (Kassabova 2017: xv). This story comprises numerous different stories that create a palimpsestic reading, as they all appear as layers upon layers emerging from this border region over time and from diverse perspectives. Hence, Kassabova for instance traces the story of one of the last Cold War victims of the border and talks to border guards as well as today's refugees along the "Balkan Route". At the border, refugees, migrants, travellers, border police, and guards meet on different temporal levels through their stories.

In the following, the focus lies on exploring in which ways this generically exceptional text presents and creates the border as a palimpsest of different temporalities and geographies, of visible and invisible as well as external and internal borders, and also of political and mythical borders. In her text, Kassabova complicates the depiction of the border and compared to The Border Handbook thus deepens and expands the palimpsestic structure.

The particular border which is addressed in the book, the author argues, distinguishes itself due to three reasons, which I read as three layers: "One, because 
of unfinished business from the Cold War; two, because it is one of Europe's great wildernesses; three, because it has been a continental influence ever since there have been continents" (Kassabova 2017: xv). The border can thus only be represented and understood in its complexity by realising how it is made up: first by a political layer, second by the layer of nature and geography, and third by the historical layer. By providing historical background on the 1980s in Bulgaria, where its inhabitants come into contact with people from abroad who spend their holidays on the Bulgarian beaches, the Iron Curtain, and imaginations about those who manage to leave Bulgaria - the "non-returnees" (Kassabova 2017: 9) - the significance of the border becomes palpable step by step.

Hence, two central instances of power that the border exercises are presented; first, the political border, when Kassabova writes: "An actively policed border is always aggressive: it is where power suddenly acquires a body, if not a human face, and an ideology" (Kassabova 2017: xvi). This political border outside is complemented by a second layer, the border inside - the psychological border created by propaganda and subsequent internalisation: "As it slowly dawned on you why the border was there (so that people like us couldn't leave), you developed a permanent border-like feeling inside you, like indigestion" (Kassabova 2017: 9). Like A Short Border Handbook, this text narrates the border of the totalitarian system as a complex palimpsest of borders: outside and inside, political as well as psychological.

This particular border in Bulgaria affects different cultures and nationalities, Kassabova elucidates, since Germans, Poles, Czechs, Hungarians, and Russians tried to cross it, which in turn creates a palimpsest of experiences and stories from different cultural backgrounds, while it especially resembled a prison for the Bulgarians: "Bulgaria had a deceptively friendly reputation for its 'green border', much easier to cross than the Berlin Wall. The most frequent victims of this border, however, were the Bulgarians; over the course of the Cold War, hundreds were shot, sometimes women and children. Hundreds escaped too" (Kassabova 2017: 49).

This border zone has always been a thoroughfare where the historical layers of stories have created a thick palimpsest:

This had been an active thoroughfare until the Cold War. Many of the refugees from the Balkan Wars and the subsequent three wars (World Wars I and II and the Greek Civil War) had buried possessions and money along the way. Marauding bands of all stripes - Greeks, Turks, Bulgarians, a United Nations of roadside thuggery - robbed refugees, tradesmen, partisans, and each other. (Kassabova 2017: 246) 
In this border zone not only stories accumulate but the material dimension in the form of "buried possessions and money" tells stories of buried identities and buried lives. The palimpsest can thus be read as a very tangible one here, while only its stories manage to visualise the border as a field of tension, of gain and loss.

Kassabova draws attention to the fact that even if old borders may have lost their political significance, yet new borders exist which affect the refugees along the "Balkan Route": "The Turkish-Bulgarian and Turkish-Greek borders have lost their old hardness but acquired a new one: its symptom is the new wire walls erected to stem the human flow from the Middle East" (Kassabova 2017: xvii). Hence, Thrace as the "checkpoint between Europe and Asia" (Kassabova 2017: 123) acquires a new significance while all - culturally, nationally, and temporally - different stories that create and narrate the border still remain present and legible. In one moment in Kassabova's journey, an encounter elucidates the role of memory and of storytelling as well as the characteristics of the border as a palimpsest of vastly different layers: "II guess all the fugitive stories are forgotten now,' I said, prodding. -'No,' Galen opened his eyes. 'Everything is remembered. Everything."' (Kassabova 2017: 250). Apart from uncovering the historical layers made up of innumerable stories, Kassabova draws attention to the new layers of stories that continue expanding the palimpsest as a parchment where stories are continually written on top of each other. Hence, the book is "DEDICATED TO THOSE WHO DIDN'T MAKE IT ACROSS, THEN AND NOW" (Kassabova 2017: non pag.).

The unconscious layers of the palimpsest are intricately intertwined with politics and geography: "It may be that all borderlands hum with the frequencies of the unconscious; after all, borders are where the fabric is thin" (Kassabova 2017: xv). Without evoking the internalised border of totalitarian systems, this quote hints at the unconscious, psychological dimension of the border palimpsest - a layer that reaches deeper than the others and creates and in turn is created by those, be they political or geographical.

As a matter of fact, this unconscious layer is intimately connected to Kassabova's personal story and the border she experienced as a child growing up in Bulgaria; therefore, one of the motivations for her journey is the desire to see the forbidden places of her childhood and "to meet the people of a terra incognita" (Kassabova 2017: xvii). In the process, she discovers that this "terra incognita" also signifies an unconscious place inside herself which is influenced by the border she was confronted with as a young girl. As a self-avowed cosmopolitan, she discovers step by step that her journey to the borderlands for writing the book turns out to be a journey to find herself. One of the people she talks to and shares stories with on her travels, Ahmed, thus tells her: "'You don't know what you are, sister. That's why you're here." (Kassabova 2017: 
149). Travelling to the borderlands and uncovering the palimpsest of borders make it possible for her to discover her own story shaped by the border, since at one point she reflects: "It's precisely when you have lost your roots that everywhere you go matters hugely" (Kassabova 2017: 77).

The border zone that Kassabova visits is a space of liminality, of in-betweenness, which is already indicated by the subtitle "A Journey to the Edge of Europe". The palimpsestic structure of the border and the borderland concerning time and history becomes visible in particular when Kassabova stresses the fact that the corridors and routes have not changed during history for trade, travel, and migration, as many different people have travelled along them in turn having left behind a palimpsest of stories that she attempts to uncover:

They don't change. Everything else changes, except the corridors. Heroine travels from Asia to Europe. Cocaine travels from Latin America to Europe, Turkey, and the Arab states. Humans travel from Asia via the main sorting country (Turkey) into Europe. The corridors once used by the Palestinians and the Kurdish rebels are now used by refugees and all manners of fugitives. The corridors used in the Cold War remain the same. Only the direction of travel has changed. (Kassabova 2017: 175)

The word "corridors" evokes liminal, in-between space similar to the use of the terms bridge and gateway for the Balkans which Kassabova reflects on: "Whenever you come to speak of the Balkans, the weary old trope of the bridge is unavoidable, but nowhere is it more observably true than in the south-east Balkans, the everyday gateway between what we are used to calling East and West" (Kassabova 2017: xvii). This liminal space between East and West is concretised and at the same time obscured by the palimpsest of borders in this borderscape. The trope of the Balkans as a bridge has of course been explored and discussed in many theoretical approaches, the most famous being Maria Todorova's study Imagining the Balkans (Todorova 2009: 1516). Consisting of an interweaving of different genres, Kassabova's text succeeds in approaching the story layers of the border and the liminality of this space from even more complex angles, while the story palimpsest in this liminal space continues to be written on in the very moment in which Kassabova explores it - most visibly by the refugees on the "Balkan Route".

Yet most of the stories of this liminal space are hidden and have to be discovered, recovered, and thus restored - similar to reading the layers of a material palimpsestic vellum. Here, Kassabova seems to invoke Yuri Lotman's concept of the semiosphere consisting of a centre and a periphery (Lotman 1990) when she states that whereas 
power is located in the centre, the borderlands are located at the periphery: "the border zones are always the periphery, always out of mainstream sight" (Kassabova 2017: xvi). Thus, the borderlands embody the liminal, as Kassabova herself concludes: "Perhaps the people of the border can tell us something about liminal spaces" (Kassabova 2017: xviii). Hence, it seems that only stories can provide an insight into the many layers that create a border, a fact which is exemplified in the instances in which Kassabova talks to many different people who are affected by the border in various ways. Instead of being presented with a one-dimensional depiction of borders as in other media, the readers of Border are led into a maze of stories - and interwoven layers.

As in Kapllani's A Short Border Handbook, in Border the issue of the impossibility of crossing a border and the simultaneous desire to transgress it play a crucial role, particularly since there are still refugees on the road for whom it proves to be highly difficult to move from one country to another. Similar to the lights across the sea visible from the Albanian shore and the forbidden radio transmissions Kapllani writes about, which are effectively ways to transgress the border, here it is the mobile phone signal that "transgresses" national borders: "It [Bulgaria] was so close to the border that a message popped up on my phone: 'Turkcell Welcomes You to Turkey"' (Kassabova 2017: 57). Again, Foucault's reflections on borders and transgression can illuminate the stories, when Kassabova writes: "Once near a border, it is impossible not to be involved, not to want to exorcise or transgress something. Just by being there, the border is an invitation. Come on, it whispers, step across this line. If you dare" (Kassabova 2017: xv), and one of the characters she talks to says: "The only good thing about a border is that you can cross it" (Kassabova 2017: 127). This actualises Foucault's statement that "Transgression carries the limit right to the limit of its being" (Foucault 1998: 28).

A border, both books reveal, consists of many interwoven layers. In dealing with similar issues as Kapllani, Kassabova almost appears to enter into a dialogue with $A$ Short Border Handbook. Hence, "border syndrome" signifies an illness which can affect everybody who has ever experienced life in a totalitarian country and thus has the "wrong passport", which is contrasted with those with the "right passport" who can freely cross the border: "For these [cross border] shoppers with their right passports, the border was something to do at the weekend, something to bring back. It was a magical line, a game for grown-up children. Now you're here. Now you've stepped across that line. The border had reverted to its natural state of bargain and barter, curiosity and commerce, tricks and tariffs" (Kassabova 2017: 132). It is striking that Kassabova proposes that in contrast to uncrossable and dangerous totalitarian borders, a "natural state" of a border exists which is characterised by excitement, adventure, "bargain", and "curiosity". With this, the text effectively presents a different conceptualisation of 
a border as a point of intercultural contact. The cross border shoppers are contrasted with today's refugees:

These ghosts - men, women, children - walked along rural roads between the border towns of Europe, with plastic bags and eyes that locals didn't want to look into for fear of seeing all the world's trouble. And while they waited for their papers to be processed, their past lives lay behind them in ruins. But they couldn't afford to mourn because of a more pressing problem: their new lives couldn't begin. (Kassabova 2017: 191)

In doing so, Kassabova portrays the liminal space in its existential form: Human beings are caught in-between, are neither here nor there, but are reduced to "ghosts" while their lives are suspended. In this context, Kassabova evokes the Greek myth of being ferried into the underworld but in a reverse fashion: "And somewhere waits a ferryman whose face can't be seen. People die crossing borders, and sometimes just being near them. The lucky ones are reborn on the other side" (Kassabova 2017: xvi).

By contrast, different border crossers - refugees, shoppers and tourists, inhabitants of the borderlands - highlight the simultaneity of different perspectives which reveals the characteristics of the borderlands as if under a magnifying glass. In "Beyond 'Culture': Space, Identity, and the Politics of Difference", Gupta and Ferguson advance a similar argument concerning the specificity of borderlands: "The fiction of cultures as discrete, object-like phenomena occupying discrete spaces becomes implausible for those who inhabit the borderlands. Related to border inhabitants are those who live a life of border crossings - migrant workers, nomads, and members of the transnational business and professional elite" (Gupta and Ferguson 1992: 7).

No wonder, then, that "border syndrome" features as a central issue in Kassabova's text on different levels and for various people. She uses the same term as Kapllani when she reacts to a story about a woman living in isolation on the border: "Maybe it was a border syndrome, I said" (Kassabova 2017: 291). This is caused by the effects of a border on human beings - the border envisioned as a palimpsest of different temporalities and geographies, of visible and invisible as well as external and internal, even unconscious borders, and of political and metaphysical borders.

\section{Conclusion: The "border syndrome" as a result of the different layers of the border}

Both texts pivot on this "border syndrome", which, I argue, is the result of the complex intertwining layers that constitute a border and the ways in which it affects 
human beings. It is particularly contemporary transcultural literature that searches for new forms and approaches to storytelling in order to explore this complexity. $A$ Short Border Handbook and Border utilise innovative genre hybrids to address the "border syndrome" caused by the dangerous effects borders have on people due to their entangled and interwoven layers.

In a time when nationalism is on the rise in many countries, whereas at the same time there have never been more refugees worldwide than today, literature can sharpen the readers' perception of the "thousand invisible borders" (Kapllani 2010: 79) that migrants are confronted with in a globalised world by giving us new - and differentiated - perspectives. At the same time, current nationalist narratives can be regarded as just more stories written on a palimpsest already marked by many stories of border crossers, of migrants, of people caught in totalitarian states in the past. A dream of a world without borders is not in the centre of both texts as such, but, as Kapllani elucidates, his dream rather consists of imagining a world without migrants, without people forced to leave their homes: "As a carrier of border syndrome, I have to confess to having a dream: a dream of a world without migrants. Don't get me wrong - I love travelling: most sufferers of border syndrome do. [...] I'd simply prefer to travel in the real sense of the world, to go travelling, like tourists do, like students do, like bohemians do [...] to travel with dignity" (Kapllani 2010: 153). In the end, Kapllani regards all human beings as migrants, even if not all of them suffer from "border syndrome": "In the final analysis, we are all migrants, armed with a temporary residence permit for this earth, each and every one of us incurably transient" (Kapllani 2010: 157).

\section{References}

Appadurai, A. (1990). Disjuncture and Difference in the Global Cultural Economy. Theory, Culture \& Society, 7, 295-310.

Decker, J. E. and D. Winchock (2017). Introduction: Borderlands and Liminality Across Philosophy and Literature. In: J. E. Decker and D. Winchock (eds.), Borderlands and Liminal Subjects: Transgressing the Limits in Philosophy and Literature, London: Palgrave Macmillan, 1-18.

Dillon, S. (2005). Reinscribing De Quincey's Palimpsest: The Significance of the Palimpsest in Contemporary Literary and Cultural Studies. Textual Practice, 19(3), 243-263.

Foucault, M. (1998). A Preface to Transgression. In: F. Botting and S. Wilson (eds.), Bataille: A Critical Reader, Oxford: Blackwell, 24-40. 
Gupta, A. and J. Ferguson (1992). Beyond 'Culture': Space, Identity, and the Politics of Difference. Cultural Anthropology, 7(1), 6-23.

Kapllani, G. (2010). A Short Border Handbook. London: Portobello.

Kassabova, K. (2017). Border: A Journey to the Edge of Europe. London: Granta.

Kinossian, N. and U. Wrakberg (2017). Palimpsests. In: J. Schimanski and S. F. Wolfe (eds.), Border Aesthetics: Concepts and Intersections, New York: Berghahn, 90-110.

Lotman, Y. (1990). Universe of the Mind: A Semiotic Theory of Culture. London: Indiana University Press.

Rogoff, I. (2000). Terra Infirma: Geography's Visual Culture. London: Routledge.

Rosello, M. and S. F. Wolfe (2017). Introduction. In: J. Schimanski and S. F. Wolfe (eds.), Border Aesthetics: Concepts and Intersections, New York: Berghahn, $1-24$.

Todorova, M. (2009). Imagining the Balkans. Oxford: Oxford University Press. 